\title{
Amanita muscaria: Ecology, Chemistry, Myths
}

\author{
Quentin Carboué * and Michel Lopez
}

URD Agro-Biotechnologies Industrielles (ABI), CEBB, AgroParisTech, 51110 Pomacle, France; michel.lopez@agroparistech.fr

* Correspondence: quentin.carbouel@agroparistech.fr

check for

updates

Citation: Carboué, Q.; Lopez, M. Amanita muscaria: Ecology, Chemistry, Myths. Encyclopedia 2021, 1, 905-914. https://doi.org/10.3390/ encyclopedia1030069

Academic Editor: Łukasz Stępień

Received: 13 July 2021

Accepted: 30 August 2021

Published: 2 September 2021

Publisher's Note: MDPI stays neutral with regard to jurisdictional claims in published maps and institutional affiliations.

Copyright: (c) 2021 by the authors Licensee MDPI, Basel, Switzerland. This article is an open access article distributed under the terms and conditions of the Creative Commons Attribution (CC BY) license (https:// creativecommons.org/licenses/by/ $4.0 /)$.
Definition: Amanita muscaria is the most emblematic mushroom in the popular representation. It is an ectomycorrhizal fungus endemic to the cold ecosystems of the northern hemisphere. The basidiocarp contains isoxazoles compounds that have specific actions on the central nervous system, including hallucinations. For this reason, it is considered an important entheogenic mushroom in different cultures whose remnants are still visible in some modern-day European traditions. In Siberian civilizations, it has been consumed for religious and recreational purposes for millennia, as it was the only inebriant in this region.

Keywords: Amanita muscaria; ibotenic acid; muscimol; muscarine; ethnomycology

\section{Introduction}

Thanks to its peculiar red cap with white spots, Amanita muscaria (L.) Lam. is the most iconic mushroom in modern-day popular culture. In many languages, its vernacular names are fly agaric and fly amanita. Indeed, steeped in a bowl of milk, it was used to catch flies in houses for centuries in Europe due to its ability to attract and intoxicate flies. Although considered poisonous when ingested fresh, this mushroom has been consumed as edible in many different places, such as Italy and Mexico [1]. Many traditional recipes involving boiling the mushroom - the water containing most of the water-soluble toxic compounds is then discarded-are available. In Japan, the mushroom is dried, soaked in brine for 12 weeks, and rinsed in successive washings before being eaten [2]. However, the fascination emanating from this mushroom is not recent or limited to culinary purposes; its consumption by humans dates back thousands of years, shaping religious and spiritual beliefs, notably in Neolithic Siberian societies. The symbolical appeal exerted by the fly agaric on our collective imagination is found in numerous representations, myths, and legends. Some examples are Lewis Caroll's Alice's Adventures in Wonderland, the Super Mario videogames series, and German artist Carsten Höller's installations. This chapter introduces various aspects of $A$. muscaria, dealing with its ecology, its chemical composition and pharmaceutical characteristics, and features of ethnomycology.

\section{Ecological Evolution and Applications}

A. muscaria is a fungus belonging to the division of the Basidiomycota, the order of the Agaricales, and the family of the Amanitaceae. The diameter of cap of the mushroom usually ranges from 4 to $21 \mathrm{~cm}$, but can reach $50 \mathrm{~cm}$. It is characterized by convex to flat shapes, and has bright red color (Figure 1). However, there are different varieties with an important phenotypic diversity, especially regarding the cap color, e.g., Amanita muscaria var. guessowii is yellow, and A. muscaria var. flavivolvata and Amanita muscaria var. inzengae are orange with yellowish warts. A. muscaria var. alba is entirely white, although it is still unclear if it is a variety of its own or a white variant of the variety flavivolvata [3]. As a remnant of the universal veil tissues, the cap is covered with white warts and the stipe has a volva limited to concentric rings $[4,5]$. 


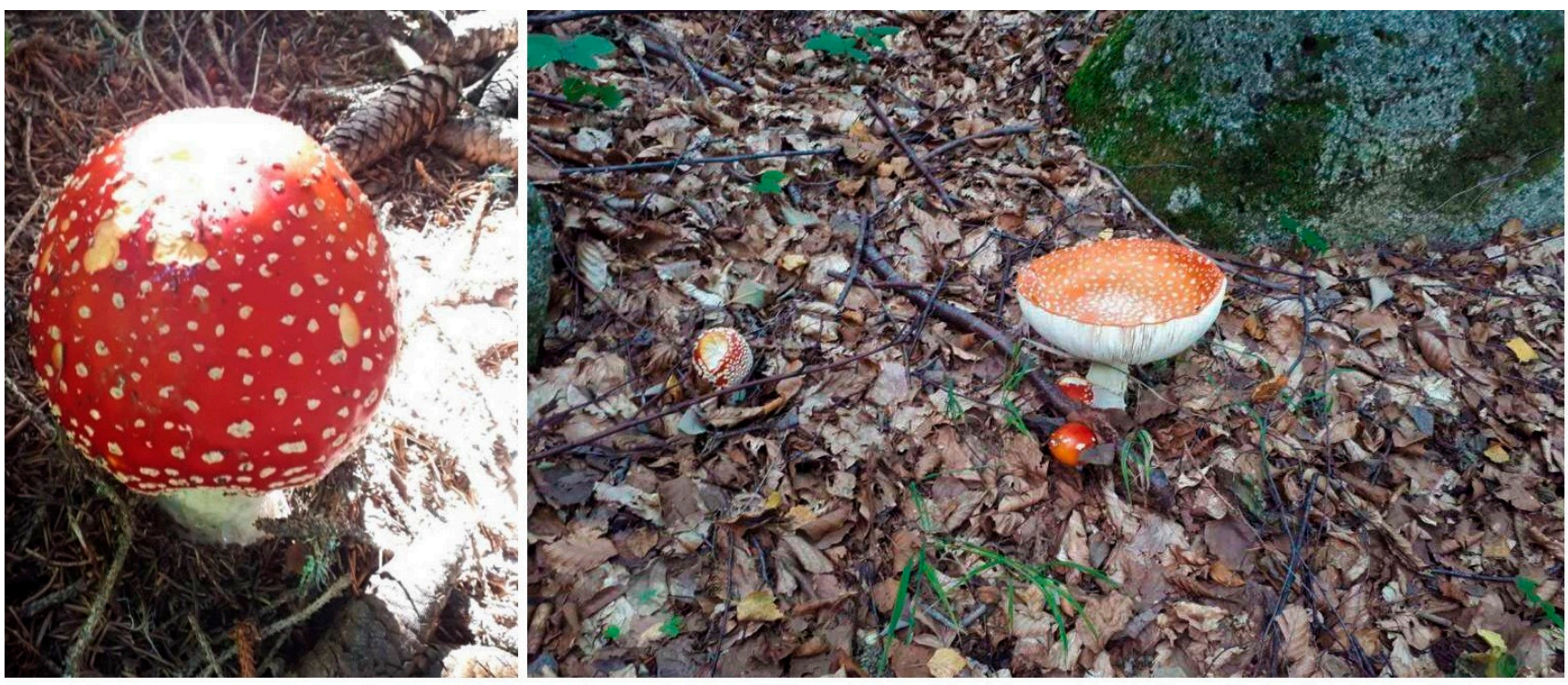

Figure 1. Basidiocarps of A. muscaria observed in the French Prealps (Alpes-de-Haute-Provence, France) (Denis Charret (C).

The basidiospores are released from the basidia during the fruiting season, usually after a rain episode [6,7]. It is an ectomycorrhizal fungus and it is usually associated with Angiospermae trees, such as Betula, Castanea, Cistus, and Quercus species, and also coniferous ones, such as Abies, Picea, and Pinus [5,8]. For this reason, on this day, it is impossible to grow A. muscaria basidiocarps in a laboratory, although it is possible to grow mycelium on synthetic media, despite a very slow growth rate [9]. A comparative genome analysis of the mitochondrial DNA suggested a common origin of the ectomycorrhizal Amanita, forming a distinct clade from the saprophyte and, therefore, non-symbiotic Amanita [10]. A. muscaria is adapted to the temperate and boreal regions of the northern hemisphere. Grown on synthetic media, temperature ranging from 11 to $23^{\circ} \mathrm{C}$ had no effect on the mushroom's respiratory activity [11]. A. muscaria usually grows in podzolic soils from deciduous and coniferous forests [12]. In these acidic soil conditions, rates of nitrogen mineralization of the leaf litter by bacteria are low, and nitrogen is mostly present under its poorly mobile ammonium and organic forms. A. muscaria possesses a high-affinity ammonium importer gene and, through the mycorrhizal symbiosis, is therefore essential in the plant nitrogen uptake in such ecosystems [13]. Phylogenetic studies indicate the existence of three distinct geographical clades (the "Eurasian", "Eurasian-Alpine", and "North American" groups) that evolved from an ancestral A. muscaria population located in the unglaciated soils of the Siberian-Beringian region-connecting Eurasia and America—during the Neogene period. This population later underwent fragmentation during its expansion on the lands [14]. This classification may evolve as new comparative genomic studies are carried out [15]. The mushroom has also been reported in the southern hemisphere, usually as an accidental consequence of the introduction of non-native trees in Chile, South Africa, New Zealand, and Australia [16-19]. In Colombia, where it was introduced through planting of nonnative trees in an effort to mitigate deforestation, it has spread to form new symbiotic interactions with native trees [20].

Fungal nutrition is carried out by absorbotrophy, meaning the mycelium absorbs and internalizes in its cells the nutrients present in the surrounding aqueous film [21,22]. Mushroom composition regarding amino acids and sugars is, therefore, influenced by the type of topsoil the mycelium is growing in [23]. This mode of nutrition also naturally allows the mushrooms to accumulate recalcitrant compounds—especially heavy metals-in their internal tissues and, notably, in the basidiocarp. This makes them interesting bioindicators for monitoring soil contaminants [24]. To be a good quality bioindicator, an organism has to be able to accumulate a compound. A. muscaria effectively accumulates $\mathrm{Hg}$ and labile forms of $\mathrm{Cd}, \mathrm{K}, \mathrm{Rb}$, and $\mathrm{V}$ - up to $0.1 \%$ of the dry mass in the lower part of the stipe, the latter 
being stabilized with ligands in the mushroom as amavadin complex [12,25,26]. A good bioindicator also has to be robust to the effect of the maturation stage on the composition of the monitored compound. This way, A. muscaria revealed very little changes in the $\mathrm{Cu}$, $\mathrm{Zn}, \mathrm{Mg}, \mathrm{Mn}, \mathrm{Se}, \mathrm{V}, \mathrm{Cd}, \mathrm{Ag}$, and As composition of its tissue over time, unlike $\mathrm{Rb}, \mathrm{Cs}, \mathrm{Pb}$, $\mathrm{Sb}, \mathrm{Tl}$, and $\mathrm{Ba}$, which were higher in younger than in mature fruiting bodies, suggesting discontinuous absorption, translocation, and accumulation processes for these metals [27]. This constant absorption of a given stable compound may vary with its radioactive isotope. In the case of radioactive cesium, an evolution of the concentration of the ${ }^{137} \mathrm{Cs}$ isotope depending on the developmental stages of the mushroom has been observed [28].

\section{Chemical Composition, Toxicity, and Potential Pharmaceutical Applications}

The fly agaric contains compounds that individually exhibit various biological activities, mainly the muscarine, the ibotenic acid, and the muscimol (Figure 2, Table 1). The combination of all these compounds can trigger a wide range of symptoms depending on the ingested quantities, the relative amounts of compounds in the mushroom, and the overall physical condition of the patient. These symptoms involve a state of inebriation, hallucinations, restlessness, increased psychomotor drive, central nervous system depression, and gastrointestinal disturbance. The usual clinical course after ingestion of a fly agaric usually starts after $30 \mathrm{~min}$ with nausea, vomiting, diarrhea, cramps, tremor, ataxia, and incoordination. After $60 \mathrm{~min}$, there is an apparition of an altered mental status characterized by declining senses, alternating between agitation and obtundation, and bizarre behaviors, involving disorientation and depersonalization. Hallucinations under the form of visual and auditory distortions are also common. Finally, later effects imply lethargy, followed by deep sleep $[29,30]$. There is no existing antidote, as symptoms are both cholinergic and anticholinergic. Treatments after ingestion usually involve gastric lavage, use of activated charcoal, and symptomatic supportive care [31]. However, the ingestion of a cap is very unlikely to lead to death, and fatal cases are very scarce. Still, a lethal dose for a human adult was calculated to be equivalent to ingesting 15 caps [32]. In addition to acute toxicity, and as previously mentioned, the mushroom is also consumed after detoxification as edible and the caps can accumulate contaminants. Therefore, the repeated consumption of mushroom harvested in contaminated areas may result in chronic toxicity related to long-term exposure to heavy metals.<smiles>CC1O[C@H](C[N+](C)(C)C)C[C@H]1O</smiles>

Muscarine<smiles>N[C@@H](C(=O)O)c1cc(O)no1</smiles>

Ibotenic acid<smiles>NCc1cc(O)no1</smiles>

Muscimol

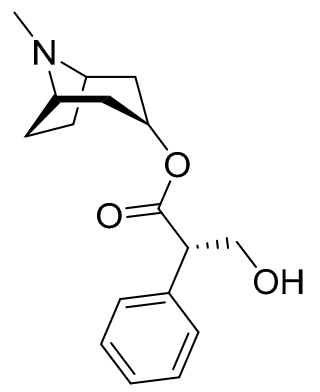

Hyoscyamine

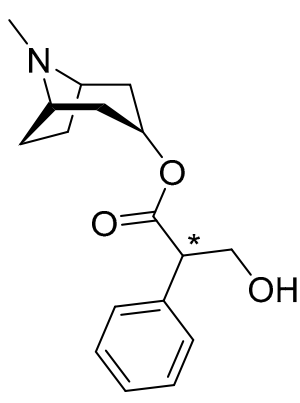

Scopolamine<smiles>CN(C)CCc1c[nH]c2ccc(O)cc12</smiles>

Bufotenine

Figure 2. Chemical structures of the main compounds found in A. muscaria. 
Table 1. Compounds and their relative quantities in the basidiocarp.

\begin{tabular}{cc}
\hline Compounds & Reported Quantities in a Mushroom (\% Dry Weight) ${ }^{\mathbf{1}}$ \\
\hline Muscarine & 0.02 \\
Ibotenic acid & 1 \\
Muscimol & 0.09 \\
Tropane alkaloids & Traces \\
\hline
\end{tabular}

${ }^{1}$ Assuming a water content of $90 \%$ and a basidiocarp weight of $70 \mathrm{~g}$ [33].

\subsection{Muscarine}

The name of this alkaloid derives directly from the A. muscaria from which it was first isolated. As a nonselective acetylcholine agonist, it acts directly on muscarinic acetylcholine receptors in the parasympathetic nervous system-one of the three divisions of the autonomous peripheral nervous system. Once fixated to a cholinergic receptor, it is not degraded by cholinesterase; hence, it has a larger duration of action on neurons than that of acetylcholine and the subsequent toxicity [34]. The nerves of this system encompass smooth muscles and glands; it has a direct influence on a variety of organs. Its action is tied to the "rest and digest" system, encompassing sexual arousal, salivation, lacrimation, urination, digestion, and defecation [35]. This compound is unable to cross the blood-brain and blood-cerebrospinal fluid barriers, preventing potential effects on the acetylcholine receptors of the central nervous system. Although it is present as trace amounts $(0.02 \%$ dry weight) in the basidiocarps, muscarine is notably responsible for the autonomic aspects of the symptoms - and, particularly, the gastrointestinal ones-upon mushroom consumption, involving perspiration, hypersalivation, lachrymation, bradycardia, diarrhea, and fatigue [36,37]. Higher concentrations of muscarine are reported in mushrooms belonging to the genera Inocybe, Inosperma and Pseudosperma [37].

Regarding biological activities, with muscarine being a neurotransmitter agonist, it exhibits a large range of actions on various neurons and endocrine cells [38-40].

\subsection{Isoxazoles Compounds}

A. muscaria contains isoxazoles compounds, mainly ibotenic acid and muscimol, but some derivatives have also been reported, such as muscazone, which is a product of ibotenic acid breakdown by UV radiation; it has a minor pharmacological activity compared with the other agents [41].

Unlike muscarine, ibotenic acid and muscimol readily cross the blood-brain barrier via an active transport system and exert their effects primarily on the central nervous system, where they act as neurotransmitter agonists [32]. Ibotenic acid acts as an agonist of the glutamate at the $N$-methyl-d-aspartate (NMDA) glutamate receptors, while muscimol is a gamma-aminobutyric acid (GABA) agonist, targeting $\mathrm{GABA}_{\mathrm{A}}$ receptor. These two compounds are the main cause of the psychotropic effects after mushroom ingestion, with muscimol accounting for the greater part, because its psychoactive dose is 10 times lower than that of ibotenic acid [42]. One fruit body of A. muscaria weighing 50-70 $\mathrm{g}$ (fresh weight) may contain around $6 \mathrm{mg}$ of muscimol and up to $70 \mathrm{mg}$ of ibotenic acid [41,43]. Therefore, sufficient levels of alkaloids are contained in one basidiocarp of a mushroom to trigger psychoactive effects in a human adult. Ibotenic acid was also detected in the spores of the mushroom [33]. After ingestion, ibotenic acid is partly metabolized to muscimol in the organism during an acidic decarboxylation step in the gastrointestinal tract. Afterwards, a part of the two compounds is carried to the brain and another part passes through the organism quickly and unmetabolized via the systemic circulation [5]. They are then excreted by the kidneys and, thus, both ibotenic acid and muscimol can be detected in human urine collected a few hours after ingestion of mushrooms [42]. In the brain, the same way muscarine is not degraded by cholinesterases, ibotenic acid and muscimol are not effectively removed from the neuronal synapse by the enzymatic systems that remove glutamate and GABA. They are then naturally excreted and almost all the ingested ibotenic acid and muscimol can be recovered in urine [29]. 
Regarding the biosynthetic pathway, seven genes belonging to the same ibo biosynthetic gene cluster and, hence, presenting in physical vicinity in the genome of A. muscaria are involved in the synthesis of muscimol. The synthesis is initiated with the hydroxylation of glutamate and six enzymes are required to form ibotenic acid from glutamate. One decarboxylase then catalyzes the formation of muscimol from ibotenic acid, with a yield of around $20 \%$ [44].

Although they have related structures, ibotenic acid and muscimol have different effects on the central nervous system. As mentioned before, muscimol is an orthosteric agonist of the GABA, the main inhibitory neurotransmitter of the mammalian central nervous system; it is, therefore, responsible for central depressant effects [45]. These psychotropic effects may be sedative, inebriant, and hallucinogenic, along with a somatic reaction involving nausea and vomiting [46].

On the other hand, ibotenic acid is an agonist of glutamate, thus inducing an excitatory effect on the central nervous system. These different actions are supported by the different syndromes observed in patients after the intoxication with A. muscaria and A. pantherina. Confusion, agitation, and euphoria are the main tendencies in the case of $A$. muscaria, in which ibotenic acid is present in higher concentrations than muscimol, and somnolence and comatose in the case of $A$. pantherina, in which muscimol is the major compound. Currently, the symptoms following intoxication with these two mushrooms share the same name: the so-called ibotenic or pantherina-muscaria syndrome; some authors suggest making a distinction to underline the specificity of each mushroom and, therefore, of each compound [47]. However, because a portion of ibotenic acid is decarboxylated into muscimol in the stomach, the complete distinction regarding the effects of each compound is difficult [48].

Regarding the biological activities, infusion of low doses of muscimol in various brain areas-ventral hippocampus, prefrontal cortex, and amygdale-involved in the emotional processes and, notably, the anxiety state participated in the disruption of Pavlovian fear memory in rats $[49,50]$. GABA, through its interaction with $\mathrm{GABA}_{\mathrm{A}}$ receptors, is known to negatively regulate the cellular proliferation in the nervous system, peripheral organs, and in tumor tissues [51]. This way, muscimol also revealed an interesting effect in the attenuation of gastric carcinogenesis progression in rats [52].

Fly agaric extract containing a high concentration of muscimol showed an interesting neuroprotection effect on rat brain synaptosomes exposed to neurotoxin 6-hydroxydopamine, significantly preserving the synaptosomal viability in comparison with control, in which the toxin led to the formation of reactive oxygen species (ROS) and reactive quinones in the cells (a process occurring in Parkinson's disease) [53]. As suggested by its name, the fly agaric is a natural insecticide. Due to the exclusive presence of glutamate-gated chloride channels in invertebrates, ibotenic acid exhibits insecticidal properties against the fly Musca domestica [54].

\subsection{Other Compounds of Interest}

The presence of tropane alkaloids is unclear, as some studies highlighted the presence of these compounds in minor quantities in some mushrooms, while their occurrence is rejected by others [5,55-58]. Those compounds include atropine, hyoscyamine, and scopolamine, which are acetylcholine antagonists; they bind to muscarinic acetylcholine receptors, blocking the action of the neurotransmitter, thus exerting a parasympatholytic action on the organism, including excitation, pupil dilatation, and repression of salivary, sweat, and gastric secretions. On the central nervous system, hyoscyamine has an excitatory effect, whereas scopolamine has a depressant action; both are classified as deliriant, meaning that the hallucinations are not recognized as unreal $[59,60]$. The presence of traces of the highly lethal amatoxins and phallotoxins-typical from Amanita phalloides-have also been reported in some fly agaric [5]. Bufotenine (5-hydroxy- $\mathrm{N}, \mathrm{N}$-dimethyltryptamine) has also been reported in various studies. Structurally, this compound is closely related to 
the psilocin (the active form of psilocybin), a fungal hallucinogenic tryptamine. Bufotenine is an agonist of serotonin on 5-HT receptors [61].

In addition, fly agaric extracts exhibit powerful antioxidant properties thanks to its high level of tocopherols-mainly $\gamma$-tocopherol and $\delta$-tocopherol—and ascorbic acid [8]. These antioxidant effects are also reported in vivo, exhibiting protection effects on human neuroblastoma cell line exposed to oxidant agents.

\section{Ethnomycology, from Ancestral Practices to Forging an Archetype}

Ethnomycology is the study of relations between human societies and fungi, involving the human dietary, medicinal, spiritual, recreational, economic, and cognitive domains [62]. This discipline is a more recent area of anthropology in comparison to ethnobotany and ethnozoology, although archeological evidence suggests that human use of fungi is at least 6000 years old [63]. Amongst these diverse interactions, hallucinogenic mushrooms share a very ancient history with men, as suggested by the parietal paintings found in Tassili $\mathrm{n}^{\prime}$ Ajjer caves in Algeria, dating back to $3500 \mathrm{BC}$ and depicting dancing human figures holding mushrooms in their hands [64].

During the classical era, the fly agaric was consumed as an entheogenic substance during ceremonies of mystery cults, such as the Dionysian Mysteries in Greece and the Mithraic Mysteries in Rome [65]. Fly agaric has also been consumed for millennia in Siberian societies-for whom hunter-gatherer culture stems directly from the Stone Agefor religious and recreational purposes, as it was the only inebriant in the area before the availability of alcohol brought by Slavic travelers, especially in the eastern part of Siberia [66]. The religious practices in Eurasia involve the Siberian shaman, through mycophagy and aided by percussive rhythm, attaining a trance state of consciousness that allows him to connect his mind with spirits [67]. As stated previously, an important part of both ibotenic acid and muscimol is excreted almost intact in urine; therefore, the tradition of drinking the urine of the shaman or of a reindeer who consumed fly agarics in order to get a second-hand stimulus was observed in some Siberian tribes [5]. Drinking a reindeer's urine after it had ingested mushrooms would also help to attenuate the unpleasant side effects [2]. The Koryaks-indigenous people from the Kamchatka Peninsula—were known to carry flasks on their sleighs for that purpose [68].

Ancient Romans believed that some mushrooms emerged from the soil in locations that were stricken by a thunderbolt. Similar beliefs regarding the lightning strike origin of the fly agaric have also been reported amongst indigenous people from Guatemala and Southern Mexico [69]. This tie is also explored in the theory established by Wasson (1971). Indeed, the author states that the fly agaric could be one of the candidates to be the Soma mentioned in the Rig Veda - one of the four Vedas, religious scriptures of Hinduism and written in Indo-Aryan language [70]. The Soma, like the Ambrosia in Greek mythology, is an elixir that gave immortality to the gods and, when consumed by the priests, had healing properties. Soma is both a god and a divine ritual drink, the god, being a personification of the drink, is himself the son of Parjanya, the Vedic Indo-Aryan god of thunder [71]. Wasson (1968) also based his theory, supported by geographic and linguistic evidence, on the Northern Eurasiatic origins of the Indo-Aryan tribes, a region where the fly agaric shamanic rituals were common, as mentioned previously [72]. The original text from the Rig Veda also details the preparation of the drink, including different steps of pressing and filtering. These purification steps could be a way to mitigate the toxicity of the mushroom, reducing the autonomic aspect of the symptoms, such as nausea and vomiting, to provide only the psychoactive effects [73]. The debate on the identity of Soma is, however, far from being over, as there is still no consensus.

Another well-known theory regarding A. muscaria, formulated in the 18th century by the Swedish naturalist Samuel Ödman, stated that Viking warriors called berserkers could undergo a state of murderous rage, the berserkergang, during battle after the ingestion of fly agaric. Nowadays, this theory is rejected, notably because of the effects induced by the ingestion of fly agaric resulting in incapacitation for the fight [74]. The henbane (Hyoscyamus 
niger), a plant rich in hyoscyamine and scopolamine, amongst other compounds, is a more serious candidate, as the substance is able to trigger the berserkergang [75].

During the Winter Solstice, the rebirth of the Sun was celebrated in all pre-Christian Europe through religious rituals and feasts to conjure luck and fertility for the new coming cycle [76]. In a syncretic approach, because of the shared attributes between Jesus Christ and the Solar Deity, the church established the birth of Christ around the Winter Solstice during the 4th century [77]. Some remnants of the pagan admixtures to Christian celebrations are still vivid. Under its obvious phallic shape, A. muscaria, along with mistletoe, was a symbol of luck and fertility, especially in the Germanic traditions. A reason that may explain the omnipresence of fly agaric on Christmas representations - cards, decorations, etc.-in Germany and Austria [78]. The modern figure of Santa Claus results in the mixing of various Christian and Northern pagan traditions (most notably, Finnish and Scandinavian). Details ranging from the white and red colors to the flying reindeers pulling his sleigh are reminders of the shamanic tradition of fly agaric ingestion [79]. Interestingly, just like $A$. muscaria that, through ectomycorrhizal interactions with pines, emerge and are harvested by the shaman under these trees, gifts are placed by Santa Claus under the green fir tree during Christmas Eve.

\section{Conclusions}

Jean-Baptiste Lamarck, the famous French naturalist who gave the actual scientific name to A. muscaria, wrote in 1815 that this mushroom is remarkable for its beauty. When walking in the woods, the powerful red color standing out in the green surroundings can only subjugate the walker. In addition to these incredible visual features, the fly agaric has a unique chemical composition, with isoxazoles, such as ibotenic acid and muscimol, whose psychoactive effects have been used for millennia and that still have not revealed all their potential concerning pharmaceutical applications. Of course, the study of ectomycorrhizal mushrooms is difficult because of the technological impossibility to fully emulate the complexity of the plant-fungus interactions to grow the mushroom in a laboratory. However, as the biology and the ecology of these micro-organisms keep on being studied and documented, new insights are made on the complexity of symbiotic plant-fungus interactions. Moreover, as new techniques emerge, new potentialities of laboratory cultivations of mycorrhizal mushrooms are glimpsed that could potentially unlock the production of very valuable compounds.

Funding: This research received no external funding.

Conflicts of Interest: The authors declare no conflict of interest.

Entry Link on the Encyclopedia Platform: https:/ / encyclopedia.pub/14889.

\section{References}

1. Rubel, W.; Arora, D. A Study of Cultural Bias in Field Guide Determinations of Mushroom Edibility Using the Iconic Mushroom, Amanita muscaria, as an Example. Econ. Bot. 2008, 62, 223-243. [CrossRef]

2. Whelan, C. "Amanita muscaria": The Gorgeous Mushroom. Asian Folk. Stud. 1994, 53, 163. [CrossRef]

3. Infraspecific Taxa of Muscaria. Available online: Amanitaceae.org (accessed on 16 August 2021).

4. Gillard, R.D.; Lancashire, R.J. Electron Spin Resonance of Vanadium in Amanita muscaria. Phytochemistry 1984, 23, 179-180. [CrossRef]

5. Michelot, D.; Melendez-Howell, L.M. Amanita muscaria: Chemistry, Biology, Toxicology, and Ethnomycology. Mycol. Res. 2003, 107, 131-146. [CrossRef] [PubMed]

6. Li, D.-W. Release and Dispersal of Basidiospores from Amanita muscaria var. Alba and Their Infiltration into a Residence. Mycol. Res. 2005, 109, 1235-1242. [CrossRef]

7. Griffin, D.H. Introduction to fungi. In Fungal Physiology; Wiley: New York, NY, USA, 1994; pp. 1-21. ISBN 978-0-471-16615-3.

8. Reis, F.S.; Heleno, S.A.; Barros, L.; Sousa, M.J.; Martins, A.; Santos-Buelga, C.; Ferreira, I.C.F.R. Toward the Antioxidant and Chemical Characterization of Mycorrhizal Mushrooms from Northeast Portugal. J. Food Sci. 2011, 76, C824-C830. [CrossRef]

9. Iotti, M.; Barbieri, E.; Stocchi, V.; Zambonelli, A. Morphological and Molecular Characterisation of Mycelia of Ectomycorrhizal Fungi in Pure Culture. Fungal Divers 2005, 19, 51-68. 
10. Li, Q.; He, X.; Ren, Y.; Xiong, C.; Jin, X.; Peng, L.; Huang, W. Comparative Mitogenome Analysis Reveals Mitochondrial Genome Differentiation in Ectomycorrhizal and Asymbiotic Amanita Species. Front. Microbiol. 2020, 11, 1382. [CrossRef] [PubMed]

11. Malcolm, G.M.; López-Gutiérrez, J.C.; Koide, R.T.; Eissenstat, D.M. Acclimation to Temperature and Temperature Sensitivity of Metabolism by Ectomycorrhizal Fungi. Glob. Chang. Biol. 2008, 14, 1169-1180. [CrossRef]

12. Falandysz, J.; Treu, R. Amanita muscaria: Bio-Concentration and Bio-Indicative Potential for Metallic Elements. Environ. Earth Sci. 2019, 78, 722. [CrossRef]

13. Willmann, A.; Weiß, M.; Nehls, U. Ectomycorrhiza-Mediated Repression of the High-Affinity Ammonium Importer Gene AmAMT2 in Amanita muscaria. Curr. Genet. 2007, 51, 71-78. [CrossRef]

14. Geml, J.; Laursen, G.A.; O’Neill, K.; Nusbaum, H.C.; Taylor, D.L. Beringian Origins and Cryptic Speciation Events in the Fly Agaric (Amanita muscaria): Phylogeography of Amanita muscaria. Mol. Ecol. 2005, 15, 225-239. [CrossRef] [PubMed]

15. Di Rita, F.; Atzeni, M.; Tudino, F. The History of Conifers in Central Italy Supports Long-Term Persistence and Adaptation of Mesophilous Conifer Fungi in Arbutus-Dominated Shrublands. Rev. Palaeobot. Palynol. 2020, 282, 104300. [CrossRef]

16. Bagley, S.J.; Orlovich, D.A. Genet Size and Distribution of Amanita muscaria in a Suburban Park, Dunedin, New Zealand. N. Z. J. Bot. 2004, 42, 939-947. [CrossRef]

17. Nouhra, E.R.; Palfner, G.; Kuhar, F.; Pastor, N.; Smith, M.E. Ectomycorrhizal Fungi in South America: Their Diversity in Past, Present and Future Research. In Mycorrhizal Fungi in South America; Pagano, M.C., Lugo, M.A., Eds.; Fungal Biology; Springer International Publishing: Cham, Switzerland, 2019; pp. 73-95. ISBN 978-3-030-15227-7.

18. Reid, D.A.; Eicker, A. South African Fungi: The Genus Amanita. Mycol. Res. 1991, 95, 80-95. [CrossRef]

19. Sawyer, N.A.; Chambers, S.M.; Cairney, J.W.G. Distribution and Persistence of Amanita muscaria Genotypes in Australian Pinus radiata Plantations. Mycol. Res. 2001, 105, 966-970. [CrossRef]

20. Vargas, N.; Gonçalves, S.C.; Franco-Molano, A.E.; Restrepo, S.; Pringle, A. In Colombia the Eurasian Fungus Amanita muscaria Is Expanding Its Range into Native, Tropical Quercus humboldtii Forests. Mycologia 2019, 111, 758-771. [CrossRef]

21. Maïga, Y.; Carboué, Q.; Hamrouni, R.; Tranier, M.-S.; Ben Menadi, Y.; Roussos, S. Development and Evaluation of a Disposable Solid-State Culture Packed-Bed Bioreactor for the Production of Conidia from Trichoderma asperellum Grown Under Water Stress. Waste Biomass Valor 2021, 12, 3223-3231. [CrossRef]

22. Schmidt, O. Wood and Tree Fungi: Biology, Damage, Protection, and Use; Springer: Berlin, Germany, 2006; ISBN 978-3-540-32138-5.

23. Deja, S.; Wieczorek, P.P.; Halama, M.; Jasicka-Misiak, I.; Kafarski, P.; Poliwoda, A.; Młynarz, P. Do Differences in Chemical Composition of Stem and Cap of Amanita muscaria Fruiting Bodies Correlate with Topsoil Type? PLoS ONE 2014, 9, e104084. [CrossRef]

24. Falandysz, J. Mercury Bio-Extraction by Fungus Coprinus comatus: A Possible Bioindicator and Mycoremediator of Polluted Soils? Environ. Sci. Pollut. Res. 2016, 23, 7444-7451. [CrossRef] [PubMed]

25. Braeuer, S.; Walenta, M.; Steiner, L.; Goessler, W. Determination of the Naturally Occurring Vanadium-Complex Amavadin in Amanita muscaria with HPLC-ICPMS. J. Anal. At. Spectrom. 2021, 36, 954-967. [CrossRef]

26. Housecroft, C.E. The Fungus Amanita muscaria: From Neurotoxins to Vanadium Accumulation. Chimia 2019, 73, 96-97. [CrossRef] [PubMed]

27. Falandysz, J.; Hanć, A.; Barałkiewicz, D.; Zhang, J.; Treu, R. Metallic and Metalloid Elements in Various Developmental Stages of Amanita muscaria (L.) Lam. Fungal Biol. 2020, 124, 174-182. [CrossRef] [PubMed]

28. Falandysz, J.; Saniewski, M.; Zalewska, T.; Zhang, J. Radiocaesium Pollution of Fly Agaric Amanita muscaria in Fruiting Bodies Decreases with Developmental Stage. Isot. Environ. Health Stud. 2019, 55, 317-324. [CrossRef]

29. Beuhler, M.C. Overview of Mushroom Poisoning. In Critical Care Toxicology; Brent, J., Burkhart, K., Dargan, P., Hatten, B., Megarbane, B., Palmer, R., Eds.; Springer International Publishing: Cham, Switzerland, 2016; pp. 1-26. ISBN 978-3-319-20790-2.

30. Łukasik-Głebocka, M.; Druzdz, A.; Naskret, M. Clinical symptoms and circumastances of acute poisonings with fly agaric (Amanita muscaria) and panther cap (Amanita pantherina). Prz. Lek. 2011, 68, 449-452.

31. Rampolli, F.I.; Kamler, P.; Carnevale Carlino, C.; Bedussi, F. The Deceptive Mushroom: Accidental Amanita muscaria Poisoning. Eur. J. Case Rep. Intern. Med. 2021, 8, 002212. [CrossRef]

32. Mikaszewska-Sokolewicz, M.A.; Pankowska, S.; Janiak, M.; Pruszczyk, P.; Łazowski, T.; Jankowski, K. Coma in the Course of Severe Poisoning after Consumption of Red Fly Agaric (Amanita muscaria). Acta Biochim. Pol. 2016, 63. [CrossRef]

33. Størmer, F.C.; Janak, K.; Koller, G.E.B. Ibotenic Acid in Amanita muscaria Spores and Caps. Mycologist 2004, 18, 114-117. [CrossRef]

34. Lurie, Y.; Wasser, S.P.; Taha, M.; Shehade, H.; Nijim, J.; Hoffmann, Y.; Basis, F.; Vardi, M.; Lavon, O.; Suaed, S.; et al. Mushroom Poisoning from Species of Genus Inocybe (Fiber Head Mushroom): A Case Series with Exact Species Identification. Clin. Toxicol. 2009, 47, 562-565. [CrossRef] [PubMed]

35. VanPatten, S.; Al-Abed, Y. The Challenges of Modulating the 'Rest and Digest' System: Acetylcholine Receptors as Drug Targets. Drug Discov. Today 2017, 22, 97-104. [CrossRef]

36. Khovpachev, A.A.; Basharin, V.A.; Chepur, S.V.; Volobuev, S.V.; Yudin, M.A.; Gogolevsky, A.S.; Nikiforov, A.S.; Kalinina, L.B.; Tyunin, M.A. Actual Concepts of Higher Fungi's Toxins: Simple Nitrogen-Containing Compounds. Biol. Bull. Rev. 2021, 11, 198-212. [CrossRef]

37. Parnmen, S.; Nooron, N.; Leudang, S.; Sikaphan, S.; Polputpisatkul, D.; Pringsulaka, O.; Binchai, S.; Rangsiruji, A. Foodborne Illness Caused by Muscarine-Containing Mushrooms and Identification of Mushroom Remnants Using Phylogenetics and LC-MS/MS. Food Control 2021, 128, 108182. [CrossRef] 
38. Shen, K.; Johnson, S.W. Presynaptic Dopamine $\mathrm{D}_{2}$ and Muscarine $\mathrm{M}_{3}$ Receptors Inhibit Excitatory and Inhibitory Transmission to Rat Subthalamic Neurones In Vitro. J. Physiol. 2000, 525, 331-341. [CrossRef]

39. Neely, A.; Lingle, C.J. Effects of Muscarine on Single Rat Adrenal Chromaffin Cells. J. Physiol. 1992, 453, 133-166. [CrossRef] [PubMed]

40. Meng, W.; Wang, S.; Yao, L.; Zhang, N.; Li, D. Muscarinic Receptors Are Responsible for the Cholinergic Modulation of Projection Neurons in the Song Production Brain Nucleus RA of Zebra Finches. Front. Cell. Neurosci. 2017, 11, 51. [CrossRef]

41. Voynova, M.; Shkondrov, A.; Kondeva-Burdina, M.; Krasteva, I. Toxicological and Pharmacological Profile of Amanita muscaria (L.) Lam.-A New Rising Opportunity for Biomedicine. Pharmacia 2020, 67, 317-323. [CrossRef]

42. Stříbrný, J.; Sokol, M.; Merová, B.; Ondra, P. GC/MS Determination of Ibotenic Acid and Muscimol in the Urine of Patients Intoxicated with Amanita pantherina. Int. J. Leg. Med. 2012, 126, 519-524. [CrossRef]

43. Ginterová, P.; Sokolová, B.; Ondra, P.; Znaleziona, J.; Petr, J.; Ševčík, J.; Maier, V. Determination of Mushroom Toxins Ibotenic Acid, Muscimol and Muscarine by Capillary Electrophoresis Coupled with Electrospray Tandem Mass Spectrometry. Talanta 2014, 125, 242-247. [CrossRef]

44. Obermaier, S.; Müller, M. Ibotenic Acid Biosynthesis in the Fly Agaric Is Initiated by Glutamate Hydroxylation. Angew. Chem. Int. Ed. 2020, 59, 12432-12435. [CrossRef]

45. Nelson, L.E.; Guo, T.Z.; Lu, J.; Saper, C.B.; Franks, N.P.; Maze, M. The Sedative Component of Anesthesia Is Mediated by GABA Receptors in an Endogenous Sleep Pathway. Nat. Neurosci. 2002, 5, 979-984. [CrossRef]

46. Stebelska, K. Fungal Hallucinogens Psilocin, Ibotenic Acid, and Muscimol: Analytical Methods and Biologic Activities. Ther. Drug Monit. 2013, 35, 420-442. [CrossRef] [PubMed]

47. Vendramin, A.; Brvar, M. Amanita muscaria and Amanita pantherina Poisoning: Two Syndromes. Toxicon 2014, 90, 269-272. [CrossRef]

48. Moss, M.J.; Hendrickson, R.G. Toxicity of Muscimol and Ibotenic Acid Containing Mushrooms Reported to a Regional Poison Control Center from 2002-2016. Clin. Toxicol. 2019, 57, 99-103. [CrossRef] [PubMed]

49. Akirav, I.; Raizel, H.; Maroun, M. Enhancement of Conditioned Fear Extinction by Infusion of the GABA Agonist Muscimol into the Rat Prefrontal Cortex and Amygdala. Eur. J. Neurosci. 2006, 23, 758-764. [CrossRef] [PubMed]

50. Hobin, J.A.; Ji, J.; Maren, S. Ventral Hippocampal Muscimol Disrupts Context-Specific Fear Memory Retrieval after Extinction in Rats. Hippocampus 2006, 16, 174-182. [CrossRef] [PubMed]

51. Young, S.Z.; Bordey, A. GABA's Control of Stem and Cancer Cell Proliferation in Adult Neural and Peripheral Niches. Physiology 2009, 24, 171-185. [CrossRef] [PubMed]

52. Tatsuta, M.; Iishi, H.; Baba, M.; Uehara, H.; Nakaizumi, A.; Taniguchi, H. Protection by Muscimol against Gastric Carcinogenesis Induced by N-Methyl-N'-Nitro-N-Nitrosoguanidine in Spontaneously Hypertensive Rats. Int. J. Cancer 1992, 52, 924-927. [CrossRef]

53. Kondeva-Burdina, M.; Voynova, M.; Shkondrov, A.; Aluani, D.; Tzankova, V.; Krasteva, I. Effects of Amanita muscaria Extract on Different in Vitro Neurotoxicity Models at Sub-Cellular and Cellular Levels. Food Chem. Toxicol. 2019, 132, 110687. [CrossRef]

54. Bowden, K.; Drysdale, A.C.; Mogey, G.A. Constituents of Amanita muscaria. Nature 1965, 206, 1359-1360. [CrossRef]

55. Satora, L.; Pach, D.; Butryn, B.; Hydzik, P.; Balicka-Ślusarczyk, B. Fly Agaric (Amanita muscaria) Poisoning, Case Report and Review. Toxicon 2005, 45, 941-943. [CrossRef]

56. Lewis, B. Atropine in Mushrooms; Therapeutic Implications. S. Afr. Med. J. 1955, 29, 262-263.

57. Wieland, T. Poisonous Principles of Mushrooms of the Genus Amanita: Four-Carbon Amines Acting on the Central Nervous System and Cell-Destroying Cyclic Peptides Are Produced. Science 1968, 159, 946-952. [CrossRef] [PubMed]

58. Subbaratnam, A.V.; Cook, W.B. Subsidiary Constituents from Amanita muscaria. J. Med. Chem. 1963, 6, 448-449. [CrossRef]

59. Osbourn, A.E.; Lanzotti, V. (Eds.) Plant-Derived Natural Products; Springer: New York, NY, USA, 2009; ISBN 978-0-387-85497-7.

60. Volgin, A.D.; Yakovlev, O.A.; Demin, K.A.; Alekseeva, P.A.; Kalueff, A.V. Acute Behavioral Effects of Deliriant Hallucinogens Atropine and Scopolamine in Adult Zebrafish. Behav. Brain Res. 2019, 359, 274-280. [CrossRef] [PubMed]

61. Debnath, B.; Singh, W.S.; Das, M.; Goswami, S.; Singh, M.K.; Maiti, D.; Manna, K. Role of Plant Alkaloids on Human Health: A Review of Biological Activities. Mater. Today Chem. 2018, 9, 56-72. [CrossRef]

62. Yamin-Pasternak, S.; Pasternak, I. Ethnomycology. In The International Encyclopedia of Anthropology; Callan, H., Ed.; Wiley: Hoboken, NJ, USA, 2018; pp. 1-2. ISBN 978-1-118-92439-6.

63. Comandini, O.; Rinaldi, A.C. Ethnomycology in Europe: The Past, the Present, and the Future. In Mushrooms, Humans and Nature in a Changing World; Pérez-Moreno, J., Guerin-Laguette, A., Flores Arzú, R., Yu, F.-Q., Eds.; Springer International Publishing: Cham, Switzerland, 2020; pp. 341-364. ISBN 978-3-030-37377-1.

64. Wieczorek, M. The Effect of Particular Active Substances of Hallucinogenic Mushrooms. Acta Univ. Lodz. Folia Biol. Oecol. 2014, 10, 40-48. [CrossRef]

65. Ruck, C.A.P.; Hoffman, M.A.; González Celdrán, J.A. Mushrooms, Myth, E Mithras: The Drug Cult That Civilized Europe; City Lights Books: San Francisco, CA, USA, 2011; ISBN 978-0-87286-470-2.

66. Lee, M.; Dukan, E.; Milne, I. Amanita muscaria (Fly Agaric): From a Shamanistic Hallucinogen to the Search for Acetylcholine. J. R. Coll. Physicians Edinb. 2018, 48, 85-91. [CrossRef]

67. Nyberg, H. Religious Use of Hallucinogenic Fungi: A Comparison between Siberian and Mesoamerican Cultures. Karstenia 1992, 32, 71-80. [CrossRef] 
68. Cunningham, N. Hallucinogenic Plants of Abuse. Emerg. Med. Australas. 2008, 20,167-174. [CrossRef]

69. Lowy, B. Amanita muscaria and the Thunderbolt Legend in Guatemala and Mexico. Mycologia 1974, 66, 188-191. [CrossRef]

70. Wasson, R.G. The Soma of the Rig Veda: What Was It? J. Am. Orient. Soc. 1971, 91, 169. [CrossRef]

71. Wasson, R.G. Soma Brought Up-to-Date. J. Am. Orient. Soc. 1979, 99, 100. [CrossRef]

72. Wasson, R.G. Soma: Divine Mushroom of Immortality; Ethno-mycological studies; Mouton: The Hague, The Netherlands, 1968; ISBN 978-0-15-683800-9.

73. Feeney, K. Revisiting Wasson's Soma: Exploring the Effects of Preparation on the Chemistry of Amanita muscaria. J. Psychoact. Drugs 2010, 42, 499-506. [CrossRef]

74. Skarstein Kolberg, A. Did Vikings Really Go Berserk? An Interdisciplinary Critical Analysis of Berserks. J. Mil. Hist. 2018, 82, 899-908.

75. Fatur, K. Sagas of the Solanaceae: Speculative Ethnobotanical Perspectives on the Norse Berserkers. J. Ethnopharmacol. 2019, 244, 112151. [CrossRef] [PubMed]

76. Rätsch, C.; Müller-Ebeling, C. Pagan Christmas: The Plants, Spirits, and Rituals at the Origins of Yuletide, 1st ed.; Inner Traditions: Rochester, VT, USA, 2006; ISBN 978-1-59477-092-0.

77. Hijmans, S. Sol Invictus, the Winter Solstice, and the Origins of Christmas. Mouseion 2003, 3, 377-398. [CrossRef]

78. Marley, G.A. Chanterelle Dreams, Amanita Nightmares: The Love, Lore, and Mystique of Mushrooms; Chelsea Green Pub: White River Junction, VT, USA, 2010; ISBN 978-1-60358-214-8.

79. Bouchard, M. Unknowingly Celebrating a Mushroom: The Influence of the Fly Agaric on Modern Yuletide Celebration. BIOL421 @UNBC_Insects, Fungi and Society. 2017. Available online: https:/ / biol421.opened.ca/unknowingly-celebrating-a-mushroomthe-influence-of-the-fly-agaric-on-modern-yuletide-celebration/ (accessed on 16 August 2021). 